(C) The Author(s), 2020. Published by Cambridge University Press on behalf of University of Notre Dame doi:10.1017/S003467052000042X

\title{
CORRIGENDUM
}

\section{Nolan Bennett: The Claims of Experience: Autobiography and American Democracy. (Oxford: Oxford University Press, 2019. Pp. ix, 257.) - CORRIGENDUM}

doi:10.1017/S0034670520000339. Published by Cambridge University Press, 2 June 2020

In the second paragraph of Smith's review of The Claims of Experience: Autobiography and American Democracy, by Bennett, ${ }^{1}$ in the August 2020 issue of Review of Politics, the book author's name was misspelled. The sentence in which the error occurred should read as follows:

In The Claims of Experience, political theorist Nolan Bennett usefully analyzes a genre, autobiography, through which an intriguing variety of public figures, who have gained prominence in very different ways, have sought to shape the imagined community of American democracy.

Additionally, Whittaker Chambers' name was misspelled twice, in the following sentences:

The autobiographical writers Bennett explores in chronological order are Benjamin Franklin, Frederick Douglass, Henry Adams, Emma Goldman, and Whittaker Chambers.

Whittaker Chambers turned from a 1930s idealism that led him to the Communist Party and friendship with Alger Hiss to disillusionment with Stalinist Russia and a quest for solace in a populist, patriotic Christianity - though Bennett rightly argues that Chambers gave more allegiance in practice to conservative statist authority than to his moral ideals.

We apologize to both Nolan Bennett and Whittaker Chambers for the errors.

${ }^{1}$ Rogers Smith, "Nolan Bennett: The Claims of Experience: Autobiography and American Democracy. (Oxford: Oxford University Press, 2019. Pp. ix, 257.)," Review of Politics 82, no. 3 (2020): 484-86. doi:10.1017/S0034670520000339. 